\title{
TYPOLOGIA JONASZ - PAWEK W NARRACJI O PODRÓŻY MORSKIEJ DO RZYMU (DZ 27,13-28,16)
}

Księga Dziejów Apostolskich jest nazywana często „monografią historyczną" pierwotnego Kościoła, która obejmuje około trzydziestu lat życia i działalności pierwszych wspólnot uczniów Chrystusa. Jak stwierdza jeden ze współczesnych autorów żydowskich, Dzieje "oferują prawdziwy wgląd w życie, sposób myślenia i aspiracje pierwszego pokolenia chrześcijan"1. Zgodnie z programem, zarówno literackim, jak i teologicznym, wyrażonym na samym początku, Księga mówi o rozszerzaniu się wiary w Jezusa, Mesjasza i Syna Bożego „w Jerozolimie, Judei, Samarii i aż po krańce ziemi" (Dz 1,8). Autor Dziejów Apostolskich - Łukasz pisze o głoszeniu Ewangelii Jezusa, które stanowiło centrum misyjnego zaangażowania Jego świadków, opowiadających z przekonaniem o życiu i nauczaniu Jezusa z Nazaretu. W świetle doświadczenia paschalnego coraz pełniej odkrywali oni także działanie Boga w Jezusie i konse-

* Ks. Paweł Podeszwa - kapłan archidiecezji gnieźnieńskiej, dr hab. nauk teologicznych, adiunkt w Zakładzie Teologii Biblijnej Wydziału Teologicznego Uniwersytetu im. Adama Mickiewicza w Poznaniu. Należy do Stowarzyszenia Biblistów Polskich, Associazione Ex Alunni/e del Pontificio Istituto Biblico w Rzymie oraz pełni funkcję moderatora Dzieła Biblijnego im. Jana Pazła II w archidiecezji gnieźnieńskiej.

${ }^{1}$ G. Vermes, Twarze Jezusa, Kraków 2008, s. 185. 
kwentnie przez Niego w życiu Jego uczniów. Ta radosna i pełna nadziei Dobra Nowina musiała dotrzeć do wielu, stąd Autor z taką pasją mówi o misyjnej działalności pierwotnego Kościoła, który na różne sposoby niesie Ewangelię coraz dalej „aż po krańce ziemi”. Łukasz tworzy zatem Księgę, która zawiera historię nie tylko pierwszych chrześcijan, ale staje się wezwaniem do takiej samej gorliwości i oddania sprawie Ewangelii wyznawców Chrystusa każdego czasu.

Niniejszy artykuł podejmuje problematykę możliwej typologii, jaką zastosował Autor Dziejów Apostolskich w rozdziałach 27-28, które opowiadają o podróży morskiej Pawła w kierunku Rzymu i przybyciu do stolicy cesarstwa. Rozpoczynamy od kilku uwag na temat Księgi Dziejów jako historiografii paradygmatycznej, następnie zostaną zasygnalizowane główne środki literackie, którymi posługuje się Łukasz, ze szczególnym uwzględnieniem typologii. Kolejno omówimy typologię Jonasz - Paweł oraz jej znaczenie paradygmatyczne i teologiczne.

\section{DZIEJE APOSTOLSKIE JAKO HISTORIOGRAFIA PARADYGMATYCZNA}

Jak wykazał ks. A. Najda w swoim opracowaniu, Dzieje Apostolskie stanowią "historiografię paradygmatyczną”2. Z jednej strony, Łukasz jest „historiografem, który spełnia prawie wszystkie wymogi formalne "grecko-rzymskiego historyka»"3, z drugiej, będąc historykiem,

Łukasz pozostaje teologiem i dlatego nie da się go zakwalifikować do któregoś z kierunków historiografii grecko-rzymskiej. Dokonuwa 2011.

${ }^{2}$ A. J. Najda, Historiografia paradygmatyczna w Dziejach Apostolskich, Warsza-

${ }^{3}$ Tamże, s. 372. Według J. Kręcidło, Dzieje Apostolskie na tle starożytnej historiografii, BPT 1 (2008), s. 32, najważniejsze standardy pisania historii wypracowane przez historiografię grecką i częściowo zaadaptowane przez rzymską, które wykorzystuje Łukasz, to: 1) obwieszczony w prologu zamiar pisania dzieła historycznego, będącego opowiadaniem o czynach i słowach; 2) odwołanie się do źródeł mówionych i pisanych, z których ma korzystać; 3) krytyczne korzystanie z tych źródeł; 4) zakorzenienie narracji w konkretnym kontekście czasowym i przestrzennym; 5) dbałość o rzetelne zbadanie oraz obiektywne i prawdziwe przedstawienie wydarzeń; 6) teologiczna orientacja dzieła, wpisująca się w metodologię wypracowaną przez Herodota. Mimo tych wymienionych podobieństw z literaturą grecko-rzymską, autor stwierdza jednoznacznie oryginalność Dziejów Apostolskich: „Dz są utworem nieznajdującym ścisłej gatunkowej paraleli $w$ antycznej literaturze. Należy je więc traktować jako oryginalny wytwór wczesnochrześcijańskiej historiografii". 
je selektywnego spojrzenia na wydarzenia historyczne $\mathrm{z}$ pierwszych dziesięcioleci chrześcijaństwa, zauważa w nich i podkreśla działania Boga. Przedstawia historię zbawczą, to znaczy „«historię Boga z ludźmi”. W taki sposób prezentuje poszczególne epizody, które są jedynie partiami tej historii, że czytelnik ma wrażenie, jakby sam uczestniczył w opisywanych wydarzeniach. Łukasz pragnie bowiem nie tyle informować, ile formować swoich czytelników. W tym celu pisze w Dziejach historię paradygmatyczną. Skupia się nie tyle na opisywaniu tego, co zdarzyło się w przeszłości, lecz bardziej na ukazaniu tego, co może się wydarzyć zawsze, w każdym czasie istnienia Kościoła. Tworzy paradygmaty, które stanowią swoiste wzorce czy modele i, podobnie jak obrazy malarskie, przemawiają do ludzi wszystkich czasów ${ }^{4}$.

Możemy zatem zapytać: o jakie paradygmaty chodzi Autorowi Dziejów Apostolskich?

Uważna analiza Księgi pozwala wydobyć kilka charakterystycznych paradygmatów: przede wszystkim paradygmat historii, przez który „,autor poucza czytelników, że to Bóg jest Panem historii, który przez Ducha Świętego przemawia do ludzi, i to zarówno jednostek, jak i do grup, umacnia ich i kieruje ich losami oraz że Jego panowanie i prowadzenie historii potwierdzają liczne znaki i cuda"5.

Następnie mamy paradygmaty postaci: pierwszoplanowych, jak Piotr i Paweł', ale także drugoplanowych, jak: Szczepan, Filip, Barnaba, Jakub, Apollos, Pryscyla i Akwila ${ }^{7}$, oraz epizodycznych, jak: Ananiasz, Lidia, Sylas, Tymoteusz, Korneliusz, Ananiasz i Safira, Szymon Czarnoksiężnik, Bar-Jezus, siedmiu synów Skewasa ${ }^{8}$. Te postaci zostają ukazane w Dziejach jako pozytywne paradygmaty „różnych postaw, czynów, świadectw, wyborów, działań, cnót czy osiągnięć i mają znaczenie uniwersalne. Postrzegać je należy jako wzorce do naśladowania dla chrześcijan wszystkich czasów. Niektóre zaś z postaci epizodycznych, np. Ananiasz i Safira, Szymon Czarnoksiężnik, Bar-Jezus, siedmiu synów Skewasa, funkcjonują i dopełniają realizm kreowanego obrazu jako pa-

\footnotetext{
${ }^{4}$ A. J. Najda, Historiografia paradygmatyczna, s. 373.

${ }^{5}$ Tamże. Szerzej na temat paradygmatu historii w Dziejach Apostolskich por. tamże, s. 181-232.

${ }^{6}$ Por. tamże, s. 233-277.

7 Por. tamże, s. 277-293.

${ }^{8}$ Por. tamże, s. 294-307.
} 
radygmaty negatywne i mają ostrzegać chrześcijan przed powielaniem ich postaw, zachowań, wyborów i działań"9.

Obok paradygmatu historii i postaci odnajdujemy w Dziejach Apostolskich wzorce wspólnoty Kościoła ${ }^{10}$. Kolejny raz przywołajmy słowa ks. Najdy:

Łukasz ukazuje, że Kościół jako składający się z Żydów i pogan nowy Lud Boży jest jedynym reprezentantem i kontynuatorem Izraela. Tłumaczy też, że prowadzona przez chrześcijan pod kierunkiem Ducha Świętego działalność ewangelizacyjna, która przynosi owoce w postaci ciągłego rozwoju Kościoła i nieustannego wzrostu liczby wierzących, ma na celu zbawienie wszystkich ludzi. Zwraca jednocześnie uwagę na organizację wspólnoty i istniejące $\mathrm{w}$ niej grupy $\mathrm{z}$ apostołami na czele oraz na ich rolę i zadania, jakie mają do spełnienia. Przedstawia również pierwszych chrześcijan, którzy, trwając „w nauce apostołów, we wspólnocie, w łamaniu chleba i w modlitwach" (2,42), tworzą idealną wspólnotę miłości. Obok wspólnoty dóbr cechuje ją i wyróżnia jedność, zgoda, solidarność, radość i wzajemna odpowiedzialność za siebie, wyrażająca się w konkretnych działaniach i pomocy materialnej wszystkim potrzebującym jej członkom ${ }^{11}$.

Ukazując wzorce do naśladowania przez chrześcijan każdego czasu, Księga Dziejów Apostolskich staje się swego rodzaju obrazem Kościoła pierwszego wieku, który jednocześnie jest swoistym „lustrem dla teraźniejszości"12.

\section{ZASTOSOWANE ŚRODKI LITERACKIE}

Według starożytnej chrześcijańskiej tradycji z VI wieku Łukasz był malarzem ${ }^{13}$. Można by zatem powiedzieć, że podobnie jak artysta

9 Tamże, s. 374.

${ }^{10}$ Por. tamże, s. 308-370.

11 Tamże.

${ }^{12}$ Por. K. Backhaus, Lukas der Maler: Die Apostolgeschichte als intentionale Geschichte der christliche Erstepoche, w: K. Backhaus, G. Häfner, Historiographie und fiktionales Erzählen. Zur Konstruktivität in Geschichtstheorie und Exegese, Neukirchen-Vluyn 2007, s. 49.

${ }_{13}$ Por. S. Gądecki, Wstęp do ewangelii synoptycznych, Gniezno 21999, s. 102. Autor wspomina Teodora Lektora, który podaje, że cesarzowa Eudoksja przesłała do Pulcherii ikonę Maryi namalowaną przez Łukasza. Być może właśnie ta notatka dała początek przekonaniu, że Łukasz był również malarzem. Por. także M. Bednarz, Bierz i czytaj. 
malarz do stworzenia obrazu potrzebuje odpowiednich materiałów, tak samo Łukasz, malując słowem ${ }^{14}$, korzysta $\mathrm{z}$ odpowiednich środków wyrazu, które pozwalają mu stworzyć piękny literacki portret ${ }^{15}$. Jakie są zatem owe literackie "farby i kolory", używane przez Łukasza w Dziejach Apostolskich, aby były ciągle aktualnym obrazem, w którym można odnaleźć sens historii, ponadczasowe wzorce postępowania chrześcijan i model życia wspólnoty Kościoła każdego czasu?

Przywołując jeszcze raz wyniki badań ks. Najdy ${ }^{16}$, do najważniejszych środków literackich wykorzystanych w Dziejach Apostolskich jako historiografii paradygmatycznej należy zaliczyć przede wszystkim tzw. przemilczenia, to znaczy opuszczenia pewnych epizodów, które znamy z innych pism Nowego Testamentu. Najbardziej wymownym przykładem jest pominięcie całkowicie w Dziejach tzw. konfliktu antiocheńskiego (Ga 2,11-14) między Pawłem a Piotrem. Te pominięcia świadczą o tym, że Autor nie miał zamiaru stworzyć wyczerpującej pod względem faktograficznym historii chrześcijan, do materiału podchodzi zatem selektywnie, ale jednocześnie ma świadomość pisania "całkowitej historii chrześcijaństwa”. Łukasz przemilcza te wydarzenia, które mogą w jakiś sposób „zakłócać” idealny obraz pierwotnego chrześcijaństwa. Chodzi przecież o historię paradygmatyczną, a więc cały akcent jest położony na to, co pozytywne, dobre, godne zachowania w pamięci i naśladowania. A nawet jeśli pojawiają się pewne paradygmaty negatywne, jak to zostało wcześniej powiedziane, to są to raczej postaci i wydarzenia epizodyczne, jakby na marginesie tej pozytywnej i godnej naśladowania historii chrześcijaństwa.

Ewangelia św. Eukasza (1,1-8,56), Tarnów ${ }^{2} 2000$, s. 35, który przyznaje, że być może jest to tylko zwykła legenda, ale może mieć ona swoje źródło w tym, że „Łukasz jako pisarz posiadał niezwykłe zdolności artystyczne"; por. także A. Grün, Jezus - wizerunek Człowieka. Ewangelia św. Łukasza, Kraków 2002, s. 21-25.

${ }^{14}$ Zob. K. Huizing, Lukas malt Christus ein literarisches Porträt, Düsseldorf 1996.

15 A. Grün, dz. cyt., s. 22: „Łukasz otrzymał greckie wykształcenie retoryczne. Celem retoryki było «odmalowanie stanu rzeczy"» [...]. Horacy mówi o «malowaniu słowami». Łukasz opanował tę sztukę i słowami maluje literacki portret Jezusa". Autor odnosi to zdanie do Ewangelii według św. Łukasza, ale powszechnie przyjmuje się, że ten sam Łukasz jest Autorem Dziejów Apostolskich, które stanowią drugą część podwójnego dzieła Łukaszowego, por. M. F. Bird, The Unity of Luka-Acts in Recent Discussion, JSNT 29 (2007), s. 425-448. Zatem warsztat literacki obu dzieł jest podobny. Zdaniem M. Bednarza, dz. cyt., s. 35: „pióro w jego ręku stawało się pędzlem, zdolnym odtworzyć w sposób niezwykle żywy cechy przedstawianych osób".

${ }^{16}$ Por. A. J. Najda, Historiografia paradygmatyczna, s. 375-381. 
Na tej samej linii sytuuje się tzw. idealizacja. Pojawia się ona zwłaszcza wobec postaci pierwszoplanowych, takich jak Piotr i Paweł, grona apostolskiego, a także w odniesieniu do wspólnoty chrześcijańskiej. Łukasz ukazuje swoje postaci jako wzorce godne naśladowania w odwadze i gorliwości głoszenia Ewangelii Jezusowej „aż po krańce ziemi” $(1,8)$, a pierwotna wspólnota jerozolimska staje się idealnym obrazem pierwotnego Kościoła, gdzie

wszyscy postępowali zgodnie z nauką apostołów, żyli we wspólnocie braterskiej, łamali chleb i modlili się. A wszystkich ogarniał lęk, gdyż apostołowie czynili wiele cudów i znaków. Wszyscy wierzący stanowili jedno i wszystko mieli wspólne. Sprzedawali swoje posiadłości i majątki i rozdzielali je wszystkim stosownie do potrzeb. Codziennie jednomyślnie gromadzili się w świątyni. Łamali chleb po domach, a pokarm przyjmowali z radością i prostotą serca. Wielbili Boga, a wszyscy ludzie odnosili się do nich życzliwie. Pan zaś codziennie pomnażał liczbę tych, którzy mieli być zbawieni (2,42-47; por. także 4,32-37; 5,12-16).

Autor Dziejów Apostolskich posługuje się także uogólnieniami i typizacją. Zacytowane wyżej summarium odnoszące się do życia pierwotnej wspólnoty chrześcijańskiej jest tego doskonałym i wymownym przykładem. Jak stwierdza ks. Najda:

przez uogólniające opisy trwających przez dłuższy czas stanów czy sytuacji (np. 2,43; 4,33) Łukasz przedstawia pojedyncze wydarzenia lub czyny jako typowe przykłady ogólnej sytuacji czy procesów dokonujących się wewnątrz Kościoła. Ukazane w summariach sposoby zachowania i postępowania chrześcijan oraz podejmowane przez nich konkretne czyny płynące z miłości i świadomość bycia wspólnotą Kościoła nie są czymś nadzwyczajnym, lecz stanami i działaniami typowymi dla Kościoła wszystkich czasów ${ }^{17}$.

Podobnie, kiedy Łukasz opowiada o misji ewangelizacyjnej apostołów, ukazuje w sposób typiczny, że nawrócenie i przyjęcie wiary dokonuje się przez głoszenie Ewangelii.

Skoro opowiadana historia paradygmatyczna ma być zapamiętana i przekazywana, aby ją naśladować, skoro ma nie tylko informować, ale przede wszystkim formować, powinna w jakiś sposób angażować słuchacza czy czytelnika. W tym celu Autor odwołuje się do znanego

${ }^{17}$ Tamże, s. 376-377. 
z historiografii antycznej dramatycznego stylu epizodycznego. Opowiadając o pełnych dramatyzmu wydarzeniach, losach i perypetiach swoich bohaterów, autor pełniej angażuje odbiorcę. Nie jest on tylko biernym adresatem teoretycznych wywodów, ale opowiadane historie stawiają go niejako pośrodku wydarzeń, staje się ich bohaterem, ma możliwość zaangażowania się w opowiadaną historię, odnajduje tam niejako swoje miejsce i lepiej rozumie, że ma także swoją ściśle określoną "rolę" do odegrania w toczącej się historii zbawienia.

Ważnym narzędziem literackim jest też tzw. redundancja, czyli technika powtórzenia, stosowana w celu podkreślenia i zaakcentowania najważniejszych tematów danego dzieła. Łukasz wykorzystuje ten zabieg literacki w Dziejach Apostolskich, kiedy chce przekazać odbiorcom treści o szczególnej wadze ${ }^{18}$. Typowym przykładem zastosowania tej techniki jest trzykrotny przekaz o wydarzeniu pod Damaszkiem (9,1-19a; 22,6-21; $26,12-18)^{19}$. Jednak nie chodzi tylko i wyłącznie o samo mechaniczne niemal powtórzenie. Łukasz wprowadza pewne modyfikacje, dodania, skrócenia, zmiany porządku, zmiany gramatyczne, zastąpienia ${ }^{20}$. W ten sposób stara się ukazać odmienne aspekty opowiadanego wydarzenia, stąd można mówić o kolejnych reinterpretacjach wydarzenia pod Damaszkiem: w 9,1-19a akcentuje powołanie apostolskie Pawła, druga tradycja z 22,6-21 rozumie powołanie Pawła jako świadka Jezusa, ostatni zaś przekaz w 26,12-18 uwypukla prorockie powołanie Pawła ${ }^{21}$.

\section{SYNKRISIS I TYPOLOGIA JAKO METODY TEOLOGICZNE}

Autor Dziejów Apostolskich nie jest tylko doskonałym „malarzem” posługującym się słowem z wielkim artyzmem. Jest przede wszystkim

${ }^{18}$ Por. D. Marguerat, Saul's Conversion (Acts 9,22-26) and the Multiplication of Narrative in Acts, w: C. M. Tuckett (red.), Luke's Literary Achievement. Collected Essays, Sheffield 1995, s. 130-142; R. D. Witherup, Functional Redundancy in the Acts of the Apostles: A case Study, JSNT 48 (1992), s. 67-86.

${ }^{19}$ Inne przykłady redundancji w Dziejach Apostolskich to trzykrotnie przytoczony dekret Soboru Jerozolimskiego $(15,20.29 ; 21,25)$, także w dwudziele Łk-Dz powtórzenie opisu wniebowstąpienia (Łk 24,50; Dz 1,9-11).

${ }^{20}$ Do najbardziej znaczących różnic w samej treści należy zaliczyć: reakcję współtowarzyszy podróży $(9,7 ; 22,9 ; 26,14)$ oraz wątek Ananiasza, który jest obecny $\mathrm{w}$ pierwszych dwóch przekazach, natomiast całkowicie pominięty w trzecim.

${ }^{21}$ Por. R. Orłowski, Łukaszowy przekaz o powołaniu Pawła. Studium literacko--teologiczne, Wrocław 2008, s. 47-48. Autor zwraca uwagę, że czytelnik współczesny nie jest przyzwyczajony do powtórek $w$ tekście, które wydają się przejawem obcej dla współczesnego odbiorcy mentalności lub nawet wyrazem niedoskonałości literackiej. 
teologiem. Jego rozumienie historii zbawienia jest oczywiste: Bóg nią kieruje, On jest Autorem i Sprawcą wszelkich toczących się wydarzeń. To właśnie Bóg jako Pan historii przygotował już wcześniej tę „historię Kościoła”, która jest pojmowana jako kontynuacja misji Jezusa oraz wypełnienie wcześniejszych proroctw i zapowiedzi ze Starego Testamentu. W celu wyrażenia tych dwóch podstawowych prawd Łukasz odwołuje się do tzw. synkrisis oraz typologii.

Pierwszy termin nawiązuje do retoryki greckiej i tzw. synkrisis, czyli zabiegu retorycznego polegającego na porównaniu dwóch osób lub rzeczy $^{22}$, także z wyraźnym zamiarem ich przeciwstawienia ${ }^{23}$. W Dziejach Apostolskich ta swego rodzaju konfrontacja osób służy jednak nie tyle ich przeciwstawieniu, ile podkreśleniu paralelnej historii poszczególnych bohaterów. Zastosowana przez Łukasza synkrisis służy zwłaszcza ukazaniu paralelizmu między Jezusem z Ewangelii a Piotrem z Dziejów ${ }^{24}$, Jezusem a Pawłem ${ }^{25}$, jak również między Piotrem a Pawłem w Dziejach Apostolskich $^{26}$. W ten sposób Łukasz bardzo mocno akcentuje, że misja apostołów Piotra i Pawła jest kontynuacją misji samego Jezusa, Paweł zaś jest apostołem i świadkiem Chrystusa na wzór samego Piotra, pierwszego apostoła. Mamy tutaj zatem do czynienia z czymś znacznie więcej niż tylko literackim środkiem wyrazu (paralelizm). Staje się on ważnym kryterium teologicznym rozumienia opowiadanej historii. Losy wspólnoty chrześcijańskiej są kontynuacją misji i dzieła Jezusa. Apostołowie wiernie naśladują swojego Mistrza, głoszą to samo słowo, dokonują tych samych dzieł i cudów. W ten sposób tocząca się historia staje się historią zbawienia, która obejmuje coraz to nowych i liczniejszych uczniów Jezusa $(2,47)$.

Historia chrześcijan opowiedziana w Dziejach Apostolskich jest jednak nie tylko kontynuacją misji Jezusa. Została ona przygotowana

22 Samo określenie pochodzi od czasownika sugkri,nw, który oznacza „zestawiać, łączyć coś z czymś, porównywać, tłumaczyć, wyjaśniać coś komuś". Występuje trzy razy w Nowym Testamencie: 1 Kor 2,13; 2 Kor 10,12bis, por. R. Popowski, Wielki stownik grecko-polski Nowego Testamentu, Warszawa 1995, s. 572. Forma rzeczownikowa бuүкрíøı nie występuje w Nowym Testamencie, jest natomiast używana w LXX.

${ }^{23} \mathrm{Na}$ ten temat oraz innych podobnych technik retorycznych por. C. Pellegrino, San Paolo e le radici cristiani d'Europa. Il "nuovo initio" degli Atti degli Apostoli tra narrazione e teologia, San Giorgio Jonico 2008, s. 164-165.

${ }^{24}$ Por. J.-N. Aletti, Il racconto come teologia. Studio narrativo del terzo vangelo e del libro degli Atti degli Apostoli, Bologna 22009, s. 79-82.

${ }^{25}$ Por. tamże, s. 82-90.

${ }^{26}$ Por. tamże, s. 75-79; por. także A. J. Najda, Historiografia paradygmatyczna, s. 260-261. 
przez Boskiego Reżysera znacznie wcześniej, w czasach Starego Testamentu, i prorocko zapowiedziana w losach i doświadczeniach Izraela oraz poszczególnych postaci starotestamentowych. Nie dziwi zatem fakt, że Łukasz w Dziejach Apostolskich przywołuje często teksty Starego Testamentu ${ }^{27}$, które pozwalają lepiej zrozumieć opowiadaną historię jako wypełnienie tej zapowiedzianej i przygotowanej wcześniej. W ten sposób także odniesienia do Starego Testamentu potwierdzają przekonania wiary chrześcijańskiej, a częste odwołania są wykorzystywane również po to, aby dowieść słuszności własnego punktu widzenia ${ }^{28}$. Obok odniesień bezpośrednich, cytatów i aluzji ${ }^{29}$, Łukasz stosuje też typologię ${ }^{30}$. Jak definiuje Hanson, jest to „metoda, stosowana w Nowym Testamencie i we wczesnym Kościele, polegająca na uznaniu jakiejś osoby albo wydarzeń starotestamentowych za typy albo zapowiedzi jakiejś osoby (prawie zawsze Chrystusa) albo jakiegoś znamiennego elementu czy charakterystycznego rysu religii chrześcijańskiej”31. Wymownym przykładem takiego sposobu interpretacji Starego Testamentu jest Pawłowa chrystologia „Adama”. W Rz 5,14 czytamy, że „On jest typem Tego, który miał

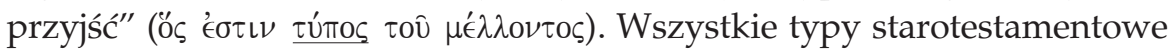
przywołane w Nowym Testamencie i odniesione do nowych rzeczywi-

${ }^{27}$ Por. J. A. Fitzmyer, Gli Atti degli Apostoli. Introduzione e commento, Brescia 2003, s. 58-64.

${ }^{28}$ Por. A. T. Hanson, Cytaty ze Starego Testamentu w Nowym Testamencie, w: B. M. Metzger, M. D. Coogan (red.), Stownik wiedzy biblijnej, Warszawa ${ }^{3} 1999$, s. 95.

${ }_{29}$ Por. J. Klinkowski, Zużytkowanie Starego Testamentu z Nowym, Legnica 2000, s. 23-39, 54-57, 207-239. Ta monografia podejmuje problematykę zastosowania przez Łukasza Starego Testamentu (cytatów, cytatów aluzyjnych oraz aluzji) w Ewangelii według św. Łukasza.

${ }^{30}$ Por. J. Czerski, Metody interpretacji Nowego Testamentu, Opole 1997, s. 236-237. Autor podkreśla, że typologia jest jednym z możliwych aspektów sensu biblijnego, zwanego sensem duchowym. Na ten temat mówi także dokument Papieskiej Komisji Biblijnej, Interpretacja Biblii w Kościele. Dokument Papieskiej Komisji Biblijnej z komentarzem biblistów polskich pod redakcja ks. Ryszarda Rubinkiewicza, Warszawa 1999, s. 65: „Jednym z możliwych aspektów sensu duchowego jest aspekt typologiczny, o którym zazwyczaj się mówi, że nie należy on do samego Pisma Świętego, ale do rzeczywistości wyrażonej przez Pismo: Adam figurą Chrystusa (por. Rz 5,14), potop figurą chrztu (1 P 3,20-21) itd. Faktycznie związek typologii zazwyczaj zasadza się na sposobie, w jaki Pismo Święte opisuje starodawną rzeczywistość (por. głos Abla: Rdz 4,10; Hbr 11,4; 12,24), nie zaś tylko pisze o tej rzeczywistości. W konsekwencji chodzi wówczas o sens Pisma Świętego" (II/B/2).

${ }^{31}$ A. T. Hanson, Typologia, w: B. M. Metzger, M. D. Coogan (red.), Stownik wiedzy biblijnej, Warszawa 1996, s. 780. 
stości, określanych jako antytypy (por. 1 P 3,21), wynikają z głębokiego przekonania, że istnieje jeden ciągły plan Boży, w którym Stary Testament jest „prefiguracją” tego wszystkiego, co Bóg uczynił w Nowym². Taka relektura Starego Testamentu w Nowym podkreśla także jedność całej Biblii $^{33}$. Zdaniem ks. Klinkowskiego,

kluczem do rozumienia stosowania Starego Testamentu przez Łukasza jest fragment: „Aż do Jana sięgało Prawo i Prorocy; odtąd głosi się Dobrą Nowinę o królestwie Bożym" $(16,16)$. [...] W ten zasadniczy model zostało wkomponowanych wiele typologii i modeli starotestamentowych, służących w mniejszych perykopach do rozwijania akcji teologicznej. W Ewangelii Łukasza toczy się ona na dwóch płaszczyznach, z jednej strony - fakty, z drugiej - znaczenie teologiczne, wydobywane przez stosowanie modeli i typologii starotestamentowych ${ }^{34}$.

Choć w pierwszym rzędzie dotyczy to Ewangelii, to jednak można przyjąć, że podobna relektura Starego Testamentu będzie obecna w drugim dziele Łukaszowym, czyli w omawianych Dziejach Apostolskich ${ }^{35}$.

Zastosowanie typologii może mieć jeszcze jedno uzasadnienie. Jak zostało powiedziane, Dzieje Apostolskie stanowią historiografię pierwotnego chrześcijaństwa. Łukasz, komponując swoje dzieło, wzorował się z pewnością nie tylko na literaturze greckiej i rzymskiej, ale przede wszystkim na historiografii żydowskiej, którą odnajdujemy w Starym Testamencie (dzieło historyczne Biblii hebrajskiej, Księgi Machabejskie) oraz literaturze pozabiblijnej (Józef Flawiusz) ${ }^{36}$. Jak wskazują komentatorzy,

${ }^{32}$ Por. B. McNeil, Typologia, w: R. J. Coggins, J. L. Houlden (red.), Stownik hermeneutyki biblijnej, Warszawa 2005, s. 894.

${ }_{33}$ Por. M. Grilli, Quale rapporto tra $i$ due Testamenti? Riflessione critica sui modelli ermeneutici classici concernenti l'unitŕ delle Scritture, Bologna 2007, s. 39-42. Włoski egzegeta pisze o modelu typologiczno-alegorycznym w chrześcijańskim rozumieniu jedności całej Biblii. Na ten temat por. także Papieska Komisja Biblijna, Naród żydowski i jego Święte Pisma w Biblii chrześcijańskiej, Kielce 2002, s. 40-41 (punkt 20 o relekturze alegorycznej, gdzie mówi się również o typologii).

${ }^{34}$ J. Klinkowski, dz. cyt., s. 242-243.

35 Przyjmujemy powszechnie raczej uznawaną opinię, że Trzecia Ewangelia (Łk) i Dzieje Apostolskie mają tego samego autora. Por. B. E. Beck, The Common Autorship of Luke and Acts, NTS 23 (1976-1977), s. 346-352. Inne odniesienia bibliograficzne por. M. Kiedzik, Łukasz - towarzysz i uczeń Pawła, w: W. Chrostowski (red.), Przybliżło się królestwo Boże. Księga pamiątkowa dla Księdza Profesora Romana Bartnickiego w 65. rocznice urodzin, Warszawa 2008, s. 229, przypis 1.

${ }^{36}$ Szerzej na ten temat por. A. J. Najda, Historiografia paradygmatyczna, s. 103-120. 
zwłaszcza Księgi Machabejskie, które opowiadają historię Hasmoneuszy od początków panowania króla Antiocha IV Epifanesa (175 r. przed Chr.) do śmierci wodza i arcykapłana Szymona (134 r. przed Chr.) oraz powstania machabejskiego (175-161 r. przed Chr.), przedstawiają działania Machabeuszy typologicznie - figurami typologicznymi (typami) są tu Dawid i Salomon ${ }^{37}$. A zatem jest możliwe, że Łukasz, naśladując w pewnym stopniu ów wzorzec, odwołuje się także w Dziejach Apostolskich do typologii jako środka literackiego i teologicznego zarazem.

\section{JONASZ TYPEM PAWŁA}

Jak zostało już powiedziane, Łukasz, posługując się synkrisis, ukazuje losy apostoła Pawła jako paralelne do losów samego Jezusa. Dotyczy to misji przepowiadania Ewangelii, a zwłaszcza oskarżeń, które są kierowane pod adresem zarówno Jezusa, jak i Pawła ${ }^{38}$. Dla Łukasza jest rzeczą oczywistą, że prorocka misja Jezusa została typologicznie zapowiedziana przez Jonasza, co wynika z ewangelicznej perykopy o znaku Jonasza (Łk 11,29-32). Warto zwrócić uwagę, że w redakcji Łukasza główny akcent został położony na osobę Jonasza, który był prorokiem Boga posłanym do mieszkańców Niniwy ${ }^{39}$. W ten sposób staje się typem prorockiej działalności Jezusa, który głosi Słowo Boże wzywające do nawrócenia i przemiany życia ${ }^{40}$. Skoro misja Jezusa została zapowiedziana przez Jonasza, a Łukasz w Dziejach Apostolskich chce ukazać dzieło Pawła jako paralelne do posłannictwa samego Jezusa ${ }^{41}$, to konsekwentnie opowiada także epizod

37 S. von Dobbler, Die Bücher1/2 Makkabäer, Stuttgart 1997, s. 44-46, cytuję za: A. J. Najda, Historiografia paradygmatyczna, s. 110, przypis 379.

38 Szczegółowe zestawienie tekstów por. J.-N. Aletti, dz. cyt., s. 82-89.

39 Redakcja Mateuszowa (12,38-42) bardziej podkreśla przebywanie Jonasza we wnętrznościach wielkiej ryby, co jest zapowiedzią misterium paschalnego Jezusa. $\mathrm{Na}$ temat znaczenia obu perykop por. A. Malina, Znak Jonasza w tradycji i redakcji synoptycznej (Mt 12,38-42; 16,1-4; Łk 11,29-32), BPT 2 (2009), s. 99-113.

40 Por. F. Mickiewicz, Ewangelia wedtug świętego Eukasza. Rozdziaty 1-11, Częstochowa 2011, s. 608. Autor zwraca także uwagę, że w redakcji Łukaszowej obecne jest odniesienie do zmartwychwstania Chrystusa, gdy mowa o mieszkańcach Niniwy, którzy powstaną na sądzie przeciwko temu pokoleniu $(11,32)$.

41 Wymownym przykładem takiego paralelizmu jest prolog i epilog Księgi. Najpierw czytamy o Jezusie: „przez czterdzieści dni zjawiał się im bowiem i mówił o królestwie Bożym” (1,3), natomiast w epilogu Łukasz pisze o Pawle: „Odważnie i swobodnie nauczał o królestwie Bożym i o Panu Jezusie Chrystusie" (28,31). Zarówno 
z życia Pawła, który typologicznie został zapowiedziany (przygotowany) przez wydarzenie z życia proroka Jonasza. Tutaj ma swoje źródło Łukaszowe zastosowanie typologii Jonasz - Paweł w Dziejach Apostolskich w opowiadaniu o burzy na morzu, rozbiciu okrętu, cudownym ocaleniu Pawła i dotarciu z Ewangelią do Rzymu $(27,13-28,16)$.

Najpierw podobieństwo jest widoczne w następstwie samych faktów ${ }^{42}$ :

Wspólny temat

Wielka burza na morzu

Wyrzucenie ładunku

Wyznanie wiary przez proroka $1,5 b-9$

Ocalenie marynarzy dzięki

prorokowi

Modlitwa proroka

Ocalenie proroka

Pobyt w brzuchu ryby trzy dni

i trzy noce, Paweł na Malcie

trzy miesiące

Prorok w wielkim mieście

pogańskim, aby głosić

Słowo Boże
Księga Jonasza

1,4

$1,5 \mathrm{a}$

27,18-19

$27,21-23$

$1,15-16$

27,24

2,2

28,8

1,13-16

$27,39-44$

28,11

$3,1-3$
28,11-16

Podobieństwo wspólnych tematów potwierdzają także zależności leksykalne. Oto najważniejsze $\mathrm{z}$ nich $^{43}$ :

misja Jezusa, jak i Pawła zostaje syntetycznie określona jako „nauczanie o królestwie Bożym”, przez które Paweł kontynuuje posłannictwo samego Jezusa. Ten motyw jest też swego rodzaju inkluzją Dziejów Apostolskich, por. J. A. Fitzmyer, dz. cyt., s. 183,849. Na temat kontynuacji misji Jezusa przez Pawła w Rzymie por. P. Podeszwa, "Trzeba, abyś w Rzymie zaświadczyt o Mnie" (Dz 23,11b). Rzym w Dziejach Apostolskich, RBL LXIV (2011) 4, s. 302-304.

${ }^{42}$ Por. C. Pellegrino, dz. cyt., s. 177.

${ }^{43}$ Tamże, s. $180-181$. 
Księga Jonasza $\left(\mathrm{LXX}^{44}\right)$

Dzieje Apostolskie

\begin{tabular}{|c|c|}
\hline 1,3a I $\omega \nu \alpha \varsigma[\ldots] \in \hat{\mathrm{U}} \rho \in \nu \pi \lambda \circ \hat{\imath} 0 \nu$ & 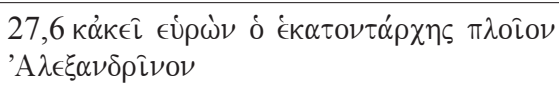 \\
\hline 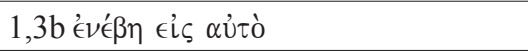 & 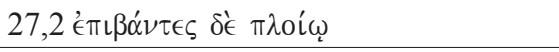 \\
\hline 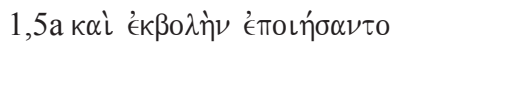 & 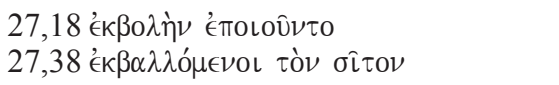 \\
\hline 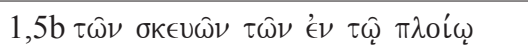 & 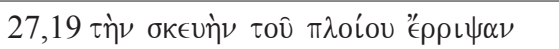 \\
\hline 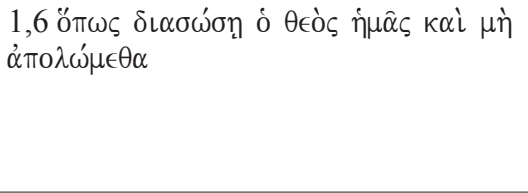 & 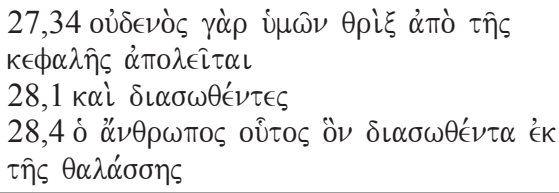 \\
\hline 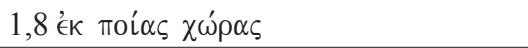 & 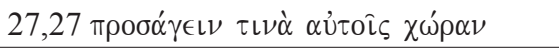 \\
\hline 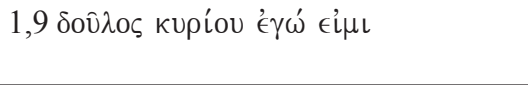 & 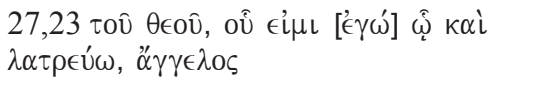 \\
\hline 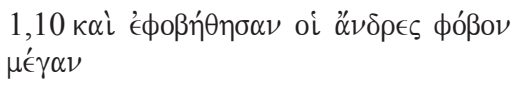 & 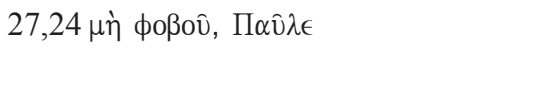 \\
\hline 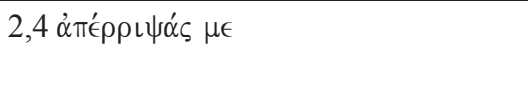 & 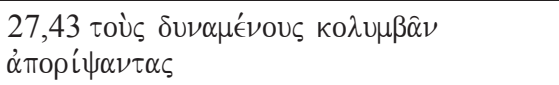 \\
\hline 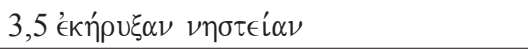 & 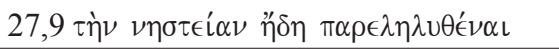 \\
\hline
\end{tabular}

Powyższe zestawienie wspólnych tematów oraz zależności leksykalnych pozwalają stwierdzić, że w zamyśle Łukasza losy Pawła są paralelne do losów proroka Jonasza ${ }^{45}$.

\section{ZNACZENIE ZASTOSOWANEJ TYPOLOGIl}

Typologia Jonasz - Paweł pozwala przede wszystkim osadzić losy Pawła na linii starotestamentowych proroków. Takie rozumienie misji Pawłowej przez Łukasza jednoznacznie potwierdzają także opisy powołań pod Damaszkiem, gdzie mamy prawdziwą "mozaikę” starotesta-

${ }^{44}$ Łukasz, podobnie jak Marek, zasadniczo posługuje się LXX. Czasami tylko dokonuje pewnych korekt stylistycznych lub teologicznych. Zresztą znaczna część cytatów Starego Testamentu w Nowym pochodzi z Septuaginty, por. M. D. Coogan, Septuaginta, w: B. M. Metzger, M. D. Coogan (red.), Stownik wiedzy biblijnej, Warszawa 1996, s. 709; por. także J. Gnilka, Teologia Nowego Testamentu, Kraków 2002, s. 7. Natomiast J. A. Fitzmyer, dz. cyt., s. 59, zwraca uwagę, że czasami cytaty pochodzą z przekładu greckiego bardzo zbliżonego do LXX („,da una traduzione greca affine a quella dei LXX”).

${ }^{45}$ Por. R. Kratz, Rettungswunder. Motiv-, traditions- und formkritische Aufarbeitung einer biblischen Gattung, Bern 1979, s. 343. 
mentowych prorockich odniesień, zwłaszcza do powołań i misji wielkich proroków, jak: Jeremiasz, Ezechiel, Sługa Jahwe czy Jonasz (zwłaszcza Dz 26,16-18 ${ }^{46}$. Tak jak kiedyś wielcy prorocy Izraela powołani przez Boga, Paweł zostaje wezwany przez Jezusa, aby Słowo Jego Ewangelii zanieść aż po krańce ziemi. Zastosowana przez Łukasza typologia ukazuje Pawła jako „drugiego Jonasza”. Obaj są prorokami posłanymi do pogan, aby głosić słowa nawrócenia. W swoim życiu i posłannictwie doświadczają konsekwentnej realizacji Bożego planu i stają się znakiem ocalenia.

W typologicznej relekturze dziejów Pawła możemy dostrzec także charakterystyczny element synkrisis, która eksponuje idee przeciwstawienia. Obaj prorocy - jak zostało powiedziane - są posłani przez Boga do pogan (Niniwa, Rzym), ponadto cel jest ten sam - głosić Boże przesłanie nawrócenia. Różnica polega jednak na tym, że Jonasz próbuje uciekać przed Bogiem i powierzoną mu misją, podczas gdy Paweł staje się paradygmatem proroka, który wiernie i odważnie realizuje swoje prorockie powołanie, mimo pojawiających się różnego rodzaju przeszkód i przeciwności. Co więcej, Paweł w obliczu niebezpieczeństwa nie traci wiary, ale wyznaje ją w sposób egzemplaryczny wobec towarzyszy podróży

${ }^{46}$ Por. A. Paciorek, Wydarzenie pod Damaszkiem w świetle nowotestamentowych wypowiedzi, w: W. Chrostowski (red.), Mów, Panie, bo stucha stuga Twój. Ksiegga pamiątkowa dla Księdza Profesora Ryszarda Rubinkiewicza SDB w 60. rocznice urodzin, Warszawa 1999, s. 169-170; R. Orłowski, dz. cyt., s. 104-109; W. Chrostowski, Mowa obronna Pawta przed królem Herodem Agryppq II podczas uwięzienia w Cezarei Nadmorskiej (Dz 26,2-23), w: W. Chrostowski (red.), Nie wstydzę się Ewangelii. Księga pamiątkowa dla Biskupa Profesora Zbigniewa Kiernikowskiego w 65. rocznice urodzin, Warszawa 2011, s. 138.

Interesujące jest odniesienie do proroka Jonasza. W powołaniu proroka Jonasza jest charakterystyczny element, który może zostać przywołany w pamięci, kiedy słyszymy o powołaniu Pawła pod Damaszkiem. Chodzi o schemat "polecenie - wykonanie”, choć w pierwszym przypadku (Jon 1,1-3) chodzi raczej o brak wykonania polecenia Boga, bo Jonasz ucieka przecież do Tarszisz, zamiast iść do Niniwy:

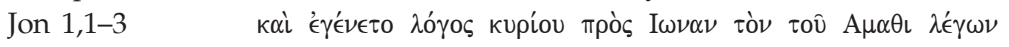

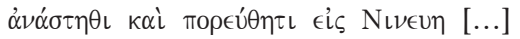

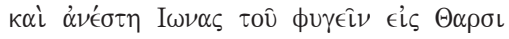

Jon 3,1-3

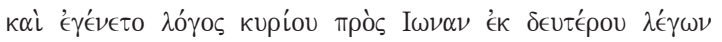

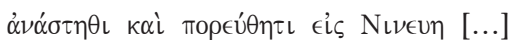

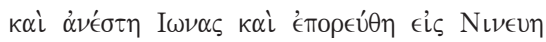

Kolejnym wspólnym elementem powołania Jonasza oraz Pawła jest misja uniwersalna. Podobnie jak Jonasz (1,2), Paweł ma być „sługą i świadkiem” Ewangelii (Dz 26,16) w odniesieniu do żydów, jak i pogan (Dz 26,17). 
$(27,23.25 .35)$, zachęcając ich do odwagi i niepoddawania się $\mathrm{w}$ trudnej sytuacji.

Ten ostatni wątek wydaje się fundamentalny dla Łukasza, który komponuje przecież Dzieje Apostolskie jako „historiografię paradygmatyczną". Paweł staje się w tej historii postacią pierwszoplanową. Wprowadzony do opowiadania na zakończenie epizodu ze Szczepanem (7,58; 8,1), począwszy od 13 rozdziału, pozostaje głównym bohaterem już do końca Księgi. Jaki jest zatem ów paradygmatyczny obraz Pawła, który wyłania się z lektury Dziejów Apostolskich?

Śledząc losy Szawła/Pawła, czytelnik Dziejów widzi go przede wszystkim jako człowieka radykalnie przekształconego, który z faryzeusza i prześladowcy staje się gorliwym i pełnym zapału uczniem i głosicielem Chrystusa. Ta przemiana ma swoje źródło w spotkaniu ze Zmartwychwstałym (9,1-19; 22,6-16; 26,12-18). Przekształcony Bożą łaską Paweł jest: wzorem świadka Chrystusa $(22,15 ; 26,16)$; apostołem jak Dwunastu $(9,15.17)$, zwłaszcza Piotr; głosicielem Ewangelii $(9,20)$ wobec Żydów $(14,1 ; 16,13 ; 17,1.10 .17 ; 18,4 ; 19,8)$ i pogan $(17,22-31)^{47}$. Łukasz ukazuje Pawła także jako paradygmat odwagi w głoszeniu Ewangelii $(9,27.28 ; 13,46 ; 14,3 ; 19,8 ; 26,26)$, interpretacji Starego Testamentu $(13,23.32-35 ; 17,3 ; 18,28 ; 26,22-23)$, nauczyciela wiary i pracy $w$ zespole $(15,40 ; 16,1-3 ; 18,2.18)$, przyjęcia i realizacji Bożego powołania (9,1-19; 22,6-16; 26,12-18), nawrócenia (9,1-19), służby Kościołowi (9,18; $11,26 ; 15,3-4)$, całkowitego oddania się Chrystusowi (21,13), pobożności i modlitwy $(13,2 ; 14,23 ; 16,25 ; 20,36)^{48}$. Jak słusznie konkluduje ks. Najda:

Podejmując próbę oceny nakreślonego w Dziejach Apostolskich obrazu Pawła, należy powiedzieć, że podobnie jak w przypadku Piotra, jest on wyidealizowany przez Łukasza. Autor, ukazując Pawła w perspektywie historycznej, w sposób paradygmatyczny ilustruje na jego osobie drogę Kościoła od judaizmu do pogaństwa. W koncepcji narracyjnej księgi Paweł uosabia bowiem zasadniczy proces historyczny i jakościową zmianę w historii zbawienia, stanowi też swoisty pomost, który łączy Jerozolimę

${ }^{47}$ Na temat mowy Pawła w Antiochii Pizydyjskiej (13,16-41) jako „modelu przepowiadania do świata żydowskiego" oraz mowy Pawła na Areopagu $(17,22-31)$ jako „Przykładu przepowiadania do oświeconego świata greckiego" por. W. Rakocy, Pawet apostot Żydów i pogan, Kraków 1997, s. 62, 118.

${ }^{48}$ Szczegółowo na temat wszystkich wymienionych paradygmatów por. A. J. Najda, Historiografia paradygmatyczna, s. 253-277. 
z Rzymem. Sygnalizuje wreszcie historiozbawczą kontynuację między starotestamentowym Izraelem a Kościołem ${ }^{49}$.

Wskazany wyżej paradygmatyczny obraz Pawła w Dziejach Apostolskich zostaje uzupełniony także przez ukazanie Pawła jako proroka Jezusa. Łukasz dokonuje tego właśnie dzięki odwołaniu się do typologii między Jonaszem i Pawłem. Ta typologia służy również wyrażeniu idei uniwersalizmu misji prorockiej Pawła. Podobnie jak Jonasz posłany przez Boga do pogańskiej Niniwy, tak teraz Paweł z woli tego samego Boga staje się apostołem i prorokiem Żydów i pogan. Swoją misję realizuje z odwagą, przynosi ona ocalenie tym, którzy są gotowi słuchać Jego słowa.

Najpierw będzie się to odnosiło do samych towarzyszy podróży. Marynarze zostają ocaleni dzięki „ofierze” Jonasza, który zostaje wrzucony w morze - w ten sposób $(1,12.15)$ burza się uciszyła i minęło niebezpieczeństwo. Uratowanie towarzyszy Pawła nie jest bezpośrednio spowodowane wyrzuceniem Pawła za burtę, ale to właśnie ze względu na niego ich życie zostaje ocalone, o czym zresztą mówi sam Paweł: „Ale teraz wzywam was, abyście się nie załamywali, bo nikt z was nie zginie. Zatonie tylko statek. Zeszłej nocy ukazał mi się anioł Boga, do którego należę i któremu służę. Powiedział mi: «Nie bój się, Pawle! Staniesz przed cesarzem. Ze względu na ciebie Bóg ocali życie wszystkim, którzy z tobą płyną»" (27,22-24). Tutaj warto podkreślić, że być może Łukasz stosuje jeszcze jedno bardzo subtelne odniesienie do typologii Jonasz - Paweł. Jak zostało powiedziane, towarzysze Jonasza ocaleli, bo on sam stał się „ofiarą", która uciszyła morską burzę. W przypadku historii Pawła mowa jest, że marynarze, bojąc się, że statek wpadnie na mieliznę, rzucili „pływającą kotwicę”50 (to. skeu/oj). To samo słowo jest odniesione do Pawła w opisie Jego powołania, kiedy Jezus zapowiada Ananiaszowi, że uczyni Pawła „narzędziem” (skeu/oj), które zaniesie Jego imię "do pogan i królów, i synów Izraela”. Można zatem widzieć tutaj aluzyjne nawiązanie do faktu, że jak Jonasz „rzucony” w morze jest przyczyną ocalenia statku i jego załogi, tak teraz Paweł "narzędzie”

49 Tamże, s. 274-275.

${ }^{50}$ Chodziło tutaj o tzw. dryfkotwę. Był to kawałek drewna, płócienny wór lub inny przedmiot na linie, który hamował statek i nie pozwalał go obrócić bokiem do wiatru, por. wyjaśnienie pojęcia w: Pismo Święte Starego i Nowego Testamentu, najnowszy przekład z języków oryginalnych z komentarzem, oprac. Zespół Biblistów Polskich z inicjatywy Towarzystwa Świętego Pawła, Częstochowa 2008, s. 2447. 
(symbolicznie rzucony w morze) jest ocaleniem dla marynarzy statku płynącego ku Rzymowi ${ }^{51}$.

Po perypetiach morskich (,trzy dni i trzy noce” Jonasza w brzuchu ryby - 2,1 oraz "trzech miesiącach" Pawła na Malcie - 28,11) obaj prorocy docierają do celu swojej podróży i wypełniają powierzoną misję głoszenia nawrócenia w Niniwie i Rzymie. Jak czytamy w Księdze Jonasza, misja proroka przyniosła oczekiwane rezultaty: mieszkańcy Niniwy przyjęli słowo Jonasza, „uwierzyli Bogu i ogłosili post” (3,4), a Bóg „zlitował się nad nimi i nie zesłał na nich nieszczęścia, które im zapowiedział" $(3,10)$. W przypadku Pawła odpowiednikiem przybycia do Niniwy jest dotarcie do Rzymu $(28,14)$ oraz misja głoszenia Ewangelii w stolicy cesarstwa (28,17-31), obejmująca zarówno Żydów $(28,17)$, jak i pogan $(28,28)$. I chociaż nie ma wzmianki o powszechnym powodzeniu misji Pawła, to jednak zakończenie Dziejów Apostolskich wskazuje na pewien uniwersalizm misji proroka, ponieważ „przyjmował wszystkich, którzy przychodzili do niego. Odważnie i swobodnie nauczał o królestwie Bożym i o Panu Jezusie Chrystusie" (28,30-31). Paweł podjął się zadania głoszenia Ewangelii i dawania świadectwa o Jezusie „z całą odwagą" (meta. pa,shj parrhsi,aj), tak jak Piotr i Jan w Jerozolimie (por. Dz 4,13), „bez przeszkód" (avkwlu,twj). To ostatnie emfatyczne stwierdzenie Łukasza na samym końcu Księgi podkreśla, że mimo iż Paweł znajduje się w areszcie domowym, słowo Boże nie uległo skrępowaniu i bez przeszkód może się rozszerzać (por. 2 Tm 2,9). W ten sposób Ewangelia Jezusa dotarła „aż po krańce ziemi” (Dz 1,8). Cel został osiągnięty, polecenie Jezusa zrealizowane, misja prorocka Pawła wykonana, Łukasz może zakończyć także swoje opowiadanie ${ }^{52}$. W ten sposób Dzieje Apostolskie są Księgą zakończoną, a jednocześnie otwartą, ponieważ słowo Boże będzie ciągle z odwagą głoszone przez następnych świadków Jezusa, którzy poniosą Jego Ewangelię po kolejne krańce ziemi ${ }^{53}$.

W tym kontekście trzeba zwrócić uwagę na jeszcze jeden bardzo ważny aspekt zastosowanej typologii. Wspomnieliśmy już wcześniej o typologii Jonasz - Jezus, przywołanej przez Łukasza w Ewangelii w perykopie o znaku Jonasza (11,29-32). Zdaniem niektórych komenta-

${ }^{51}$ Por. C. Pellegrino, dz. cyt., s. 178, przypis. 44. Autor zwraca jeszcze uwagę, że w 27,19, gdzie mowa, że na trzeci dzień pozbyto się nawet wyposażenia statku, występuje rzeczownik skeuh, który jest żeńskim odpowiednikiem rzeczownika skeu/oj z 27,17.

52 A. Decaux, Święty Pawet, Warszawa 2006, s. 229.

${ }^{53}$ Por. P. Podeszwa, "Trzeba, abyś w Rzymie zaświadczyt o Mnie”, s. 304. 
torów typologicznie można także odczytać inną perykopę Łukaszową, a mianowicie opowiadanie o uciszeniu burzy na jeziorze $(8,22-25)$, które również wykazuje na wiele podobieństw tematycznych i leksykalnych do Księgi Jonasza oraz Dziejów Apostolskich ${ }^{54}$. Jeśli uznamy, że to opowiadanie odnosi się także typologicznie do dziejów Jonasza i Jezusa, to mamy kolejny raz charakterystyczny dla Łukasza „łańcuch”: Jonasz - Jezus - Paweł, co też odpowiada doskonale jego rozumieniu historii zbawienia: Stary Testament jest tu czasem przygotowania, życie i misja Jezusa - czasem wypełnienia, a dzieje Kościoła - czasem kontynuacji.

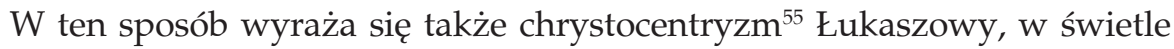
którego misja prorocka Pawła jest kontynuacją misji prorockiej Jonasza oraz samego Jezusa, „wielkiego proroka” (Łk 7,16). Łukasz, przywołując typologię Jonasz - Jezus - Paweł, przedstawia w Dziejach Apostolskich kontynuację przepowiadania od proroków do Jezusa i dalej od Jezusa do Pawła. Apostoł Paweł, który głosi wypełnienie się proroctw i oczekiwań Starego Testamentu w Chrystusie, staje się jednocześnie „prorokiem czasu mesjańskiego" ${ }^{\prime 56}$. Tak rozumiana typologia jest nie tylko wyrazem Łukaszowego odczytywania dziejów Kościoła jako realizacji dawnych

${ }^{54}$ Por. C. Pellegrino, dz. cyt., s. 180-181. Innego zdania jest F. Mickiewicz, dz. cyt., s. 434.

55 Por. A. T. Hanson, Cytaty ze Starego Testamentu, s. 95, także Papieska Komisja Biblijna, Naród żydowski, s. 39-40 (punkt 19/2, gdzie mowa o relekturze Starego Testamentu w świetle Chrystusa); por. także Benedykt XVI, Adhortacja apostolska Verbum Domini. O Stowie Bożym w życiu i misji Kościoła, Kraków 2010, nr $40-41$ (s. 47-49). Papież pisze o „oryginalności lektury chrystologicznej” Starego Testamentu w świetle Nowego, ale przypomina o konieczności odczytywania również Nowego Testamentu w świetle Starego.

Chrystocentryzm w rozumieniu i interpretowaniu Starego Testamentu zostanie rozwinięty zwłaszcza w egzegezie (także typologicznej) chrześcijańskiej pierwszych wieków, por. M. Simonetti, Między dostownościq a alegoria. Przyczynek do historii egzegezy patrystycznej, Kraków 2000, s. 17-27. Na temat chrystologicznej typologii proroka Jonasza por. P. Podeszwa, Typologia Chrystusa cierpiacego w "Komentarzu do Ksiegi Jonasza”, w: P. Podeszwa, W. Szczerbiński (red.), Ad sapientiam cordis. Księga pamiątkowa dedykowana księdzu profesorowi Ludwikowi Gtadyszewskiemu w 70. rocznicę urodzin, Gniezno 2002, s. 151-176; tenże, Prorok Jonasz zapowiedziq Chrystusa w świetle „Komentarza do Księgi Jonasza" św. Hieronima, BPT 2 (2009), s. 151-170; M. C. Paczkowski, Typologia proroka Jonasza w przepowiadaniu Piotra Chryzologa, BPT 2 (2009), s. 171-189.

56 A. J. Najda, Prorocki charakter powotania Pawta, StT 26 (2008), s. 176. Zdaniem J. Gnilki, Paweł z Tarsu. Apostoł i świadek, Kraków 2001, s. 57, Paweł „urząd apostoła cenił wyżej niż urząd proroka, jako że jemu samemu i pozostałym apostołom zostało objawione w Jezusie Chrystusie eschatologiczne zbawienie czasów ostatecznych". 
obietnic i zapowiedzi, ale wskazuje również na Chrystusa jako „środek czasu" ${ }^{\prime \prime}$, do którego zmierza Stary Testament (zapowiedź - wypełnienie) oraz podkreśla jednoznacznie, że tocząca się historia uczniów Jezusa jest skuteczną kontynuacją dzieła zbawienia w czasie i przestrzeni, które uobecnia się w mocy Ducha Świętego aż po wszystkie dni i krańce świata.

\section{THE TYPOLOGY OF JONAH AND PAUL IN THE NARRATIVE OF THE VOYAGE TO ROME (ACTS 27:13-28:16)}

\section{SUMMARY}

The article deals with potential typology of Jonah and Paul as undertaken by the author of the Acts of the Apostles (chapters 27-28), describing the Apostle's voyage to Rome and his subsequent arrival in the capital of the Empire. It starts with a number of remarks about the Book of Acts as paradigmatic historiography. The next point is devoted to discussing the main literary techniques utilized by Luke, with particular emphasis on typology. It is then followed by an analysis of the typology of Jonah and Paul as well as its paradigmatic and theological significance. The typology being used enables Luke to show Paul as a prophet of Jesus. The typology also serves to convey the idea of universalism characterizing the Apostle's prophetic mission. Just as Jonah was sent by God to a pagan city of Nineveh, now Paul, by God's will, becomes the apostle and prophet of both Jews and Gentiles. He fulfils his mission courageously thus bringing salvation to those who are ready to listen to His word.

57 Por. H. Conzelmann, Die Mitte der Zeit, Tübingen 1954. 